\title{
Assessment of cloud supersaturation by size-resolved aerosol particle and cloud condensation nuclei $(\mathrm{CCN})$ measurements
}

\author{
M. L. Krüger ${ }^{1}$, S. Mertes ${ }^{2}$, T. Klimach ${ }^{1}$, Y. F. Cheng ${ }^{1}$, H. Su ${ }^{1}$, J. Schneider ${ }^{1}$, M. O. Andreae ${ }^{1}$, U. Pöschl ${ }^{1}$, and \\ D. Rose R, $^{*}$ \\ ${ }^{1}$ Multiphase Chemistry, Biogeochemistry, and Particle Chemistry Departments, Max Planck Institute for Chemistry, \\ P.O. Box 3060, 55020 Mainz, Germany \\ ${ }^{2}$ Leibniz Institute for Tropospheric Research, Permoserstraße 15, 04318 Leipzig, Germany \\ *now at: Institute for Atmospheric and Environmental Sciences, Goethe University of Frankfurt am Main, Altenhöferallee 1, \\ 60438 Frankfurt am Main, Germany \\ Correspondence to: D. Rose (rose@iau.uni-frankfurt.de)
}

Received: 19 September 2013 - Published in Atmos. Meas. Tech. Discuss.: 15 November 2013

Revised: 15 June 2014 - Accepted: 24 June 2014 - Published: 19 August 2014

\begin{abstract}
In this study we show how size-resolved measurements of aerosol particles and cloud condensation nuclei $(\mathrm{CCN})$ can be used to characterize the supersaturation of water vapor in a cloud. The method was developed and applied during the ACRIDICON-Zugspitze campaign (17 September to 4 October 2012) at the high-Alpine research station Schneefernerhaus (German Alps, 2650 m a.s.1.). Number size distributions of total and interstitial aerosol particles were measured with a scanning mobility particle sizer (SMPS), and size-resolved $\mathrm{CCN}$ efficiency spectra were recorded with a CCN counter system operated at different supersaturation levels.

During the evolution of a cloud, aerosol particles are exposed to different supersaturation levels. We outline and compare different estimates for the lower and upper bounds ( $\left.S_{\text {low }}, S_{\text {high }}\right)$ and the average value $\left(S_{\text {avg }}\right)$ of peak supersaturation encountered by the particles in the cloud. A major advantage of the derivation of $S_{\text {low }}$ and $S_{\text {avg }}$ from size-resolved $\mathrm{CCN}$ efficiency spectra is that it does not require the specific knowledge or assumptions about aerosol hygroscopicity that are needed to derive estimates of $S_{\text {low }}, S_{\text {high }}$, and $S_{\text {avg }}$ from aerosol size distribution data. For the investigated cloud event, we derived $S_{\text {low }} \approx 0.07-0.25 \%, S_{\text {high }} \approx 0.86-1.31 \%$ and $S_{\text {avg }} \approx 0.42-0.68 \%$.
\end{abstract}

\section{Introduction}

Atmospheric aerosols consist of particles spanning a wide range of size and chemical composition from various natural and anthropogenic sources (Pöschl, 2005). They can act as cloud condensation nuclei ( $\mathrm{CCN})$ and affect climate by influencing the properties of clouds and precipitation (Lohmann and Feichter, 2005; Solomon et al., 2007; Rosenfeld et al., 2008). Depending on particle size, composition, and mixing state, aerosol particles are activated as $\mathrm{CCN}$ at different water vapor supersaturations (e.g., Köhler, 1936; Dusek et al., 2006; McFiggans et al., 2006; Andreae and Rosenfeld, 2008; Su et al., 2010).

As a result of long-term efforts and recent advances in atmospheric research, the $\mathrm{CCN}$ activity of atmospheric aerosol particles can be fairly well constrained by measurements and models (e.g., Petters and Kreidenweis, 2007, 2008; Gunthe et al., 2009; Kinne, 2009; Moore and Nenes, 2009; Pöschl et al., 2009; Juranyi et al., 2010; Pringle et al., 2010; Rose et al., 2010; Wex et al., 2010; Gunthe et al., 2011; Kim et al., 2011; Kulmala et al., 2011; Rose et al., 2011; Spracklen et al., 2011; Anttila et al., 2012; Christensen and Petters, 2012; Engelhart et al., 2012; Padró et al., 2012; Jurányi et al., 2013; Lance et al., 2013; Mikhailov et al., 2013; Petters and Kreidenweis, 2013). To fully describe the process of CCN activation and cloud droplet growth in the atmosphere, however, the supersaturation of water vapor in the cloud also needs to be known (e.g., Reutter et al., 2009; Pruppacher and Klett, 2010; Rosenfeld et al., 2012; Renno et al., 2013). 
Upon cloud formation, the decrease of temperature in an ascending air parcel resulting from the expansion of air with decreasing pressure (adiabatic cooling) or the decrease of temperature in an air parcel moving horizontally over a colder surface or air mass (isobaric cooling) induces water vapor supersaturation (Pruppacher and Klett, 2010). At the point where the increase of supersaturation by cooling is compensated by the condensational sink of water vapor, the supersaturation reaches a maximum or peak value. Following Hammer et al. (2014) we use the expression "peak" rather than "maximum" supersaturation. Particles with a critical supersaturation equal to or lower than the peak supersaturation are activated and grow into cloud droplets. The peak supersaturation is a major determinant for the cloud droplet number and the regime of $\mathrm{CCN}$ activation (aerosol- vs. updraft limited; Reutter et al., 2009; Rosenfeld et al., 2012). Due to inhomogeneities of the atmospheric aerosol load and air flow pattern (turbulence, entrainment), the peak supersaturations of different air parcels in a cloud can be temporally and spatially heterogeneous.

Techniques for the direct measurement of cloud supersaturation are not available. Thus, indirect methods have been developed to estimate the value of water vapor supersaturation in a cloud, which determines the fraction of particles that are activated and form cloud droplets.

An early approach to deduce the cloud supersaturation was presented by Hoppel et al. (1996). They commonly observed a double-peaked structure of the aerosol size distribution in the marine boundary layer, which is a result of processing aerosol through nonprecipitating cloud cycles. The authors suggest that the mode that peaks at 20 to $80 \mathrm{~nm}$ consists of particles that are too small to be activated during the cloud processing, and the mode that peaks at 160 to $400 \mathrm{~nm}$ represents the residue of evaporated cloud droplets that have been enlarged mainly as a result of liquid-phase conversion of soluble trace gases to nonvolatile compounds. Therefore, they could relate the diameter at which the minimum occurs (the so-called Hoppel minimum) to the supersaturation of the cloud, assuming the particles to consist of a mixture of ammonium sulfate and sulfuric acid.

Another method to derive the supersaturation of a cloud was used by, for example, Hammer et al. (2014), Ditas et al. (2012), Asmi et al. (2012), and Anttila et al. (2009). In these studies the fraction of activated particles in a cloud was deduced from the comparison of the number size distribution of interstitial particles (i.e., particles not taken up into cloud droplets) and total aerosol particles (i.e., cloud residuals plus interstitial particles). Through Köhler theory and with the assumption of an average particle hygroscopicity, the diameter at which $50 \%$ of all particles activated was related to the particles' critical supersaturation, which was then regarded as the supersaturation at which ambient clouds had formed.

In a recent study, Russell et al. (2013) measured the CCN activation of cloud residuals, which were sampled behind a counterflow virtual impactor (CVI) and compared it to the measured cloud droplet number concentration (CDNC). The supersaturation at which the CDNC was equal to the CCN concentration of the cloud residuals was assumed to be the cloud supersaturation.

Most likely the particles of a cloud are processed through a number of nonprecipitating cloud cycles (typically on the order of 10 or more; Hoppel et al., 1996). Thus, different particles may have been exposed to different peak supersaturations, at which they were activated into cloud droplets. For that reason the activation of aerosol particles in the cloud cannot be described or reproduced with the activation at one single supersaturation level.

In this study we derive and compare different estimates for an effective average value $\left(S_{\text {avg }}\right)$ and the lower and upper bounds ( $\left.S_{\text {low }}, S_{\text {high }}\right)$ of the peak supersaturation encountered by the particles in a cloud. Estimates of $S_{\text {avg }}$ (Sects. 3.2.1 and 3.2.2), $S_{\text {low }}$ (Sect. 3.2.3), and $S_{\text {high (Sect. 3.2.4) based }}$ on aerosol size distribution data require specific assumptions or measurements of aerosol hygroscopicity; these are not required for the derivation of $S_{\text {low }}$ (Sect. 3.1.1) and $S_{\text {avg }}$ (Sect. 3.1.2) from size-resolved CCN efficiency spectra.

\section{Experimental methods and data analysis}

\subsection{Measurement site}

Measurements were performed during the ACRIDICONZugspitze campaign (17 September to 4 October 2012) at the research station Schneefernerhaus, a mountain site in the German Alps $\left(47.42^{\circ} \mathrm{N}, 10.97^{\circ} \mathrm{E} ; 2650 \mathrm{~m}\right.$ a.s.l.; www. schneefernerhaus.de). The aim of this campaign was the investigation of liquid water clouds. For the analysis in this paper we chose one exemplary cloud event, which occurred on 19 September 2012.

\subsection{Inlet system}

We used an inlet that segregated hydrometeors by means of a cyclone with a $2.5 \mu \mathrm{m}$ cut-off $\left(\mathrm{PM}_{2.5}\right)$. During out-of-cloud conditions the inlet samples all aerosol particles with diameter $<2.5 \mu \mathrm{m}$ (total aerosol). During in-cloud conditions particles that have been activated to cloud droplets are removed because they are larger than the inlet cut-off diameter (Mertes et al., 2005). Therefore the sampled aerosol can be regarded as interstitial.

\subsection{Liquid water content (LWC)}

To distinguish between in-cloud and out-of-cloud conditions, we utilized measurements of the liquid water content (LWC), which were performed by a particle volume monitor (Gerber, 1991). As suggested also by Henning et al. (2002) we defined a period of $\mathrm{CCN}$ measurements as in cloud when the LWC was $>0.02 \mathrm{~g} \mathrm{~m}^{-3}$ for $85 \%$ of the time and as out of cloud when the LWC was $<0.02 \mathrm{~g} \mathrm{~m}^{-3}$ for $85 \%$ of the time. 


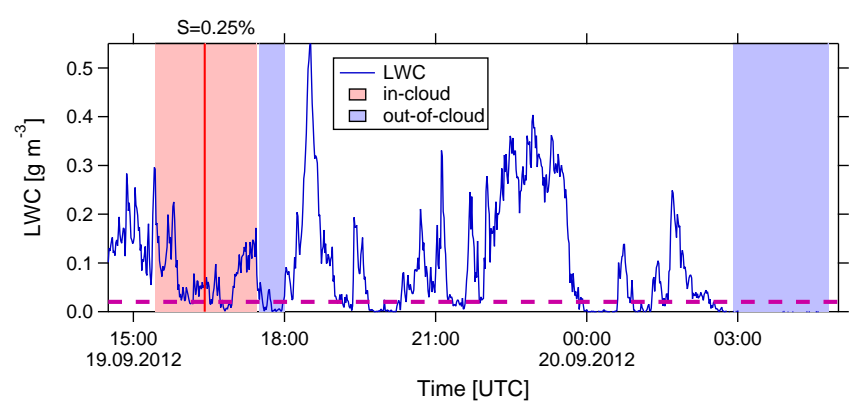

Figure 1. Time series of the liquid water content (LWC) measured by a particle volume monitor permitting distinction between incloud and out-of-cloud conditions. The time period for in-cloud conditions, during which the cloud supersaturation was investigated, is marked in red (19 September 2012, 15:26-17:17 UTC). The red vertical line indicates the time when the CCN scan at $S=0.25 \%$ was finished. Out-of-cloud conditions are marked in blue, in which the first small time period was used to apply the SMPS method (19 September 2012, 17:30-18:00 UTC). The second larger period (20 September 2012, 02:54-04:47 UTC) was used for the $\mathrm{CCN}$ method, because a longer time interval without cloud was needed to get a full $\mathrm{CCN}$ spectrum.

For the analysis in this paper we chose one exemplary cloud event, which occurred on 19 September 2012. During this event the LWC was on average $0.073 \mathrm{~g} \mathrm{~m}^{-3}$. Figure 1 shows the time series of the LWC for a certain time before, during, and after the analyzed cloud event with in-cloud and out-ofcloud conditions highlighted.

\subsection{Size-resolved CCN measurements}

The number concentration of $\mathrm{CCN}$ was measured using a continuous-flow streamwise thermal gradient $\mathrm{CCN}$ counter (CCNC), commercially available from Droplet Measurement Technologies Inc. (DMT, CCN-100). The operation principle of the CCNC is based on the fact that diffusion of heat in air is slower than diffusion of water vapor. This allows for the generation of a supersaturated area inside a flow tube by combining a temperature gradient with water vapor from a continuously wetted porous inner surface (Roberts and Nenes, 2005). The inlet flow rate of the CCNC was $0.5 \mathrm{~L} \mathrm{~min}^{-1}$, with a sheath-to-aerosol flow ratio of 10 . The water pump was operated at a rate of $4 \mathrm{mLh}^{-1}$, corresponding to the CCNC setting of "low" liquid flow. By changing the temperature gradient, the supersaturation of the CCNC was set to different values between 0.06 and $0.60 \%$. Particles with a critical supersaturation equal to or smaller than the prescribed supersaturation $\left(S_{\text {presc }}\right)$ were activated and formed water droplets. An optical particle counter (OPC) at the exit of the flow tube determined the concentration of droplets larger than $1 \mu \mathrm{m}$, which were considered to be activated CCN.
Combining the CCNC described above with a differential mobility analyzer (DMA) and a condensation particle counter (CPC), size-resolved CCN efficiency spectra at a given $S_{\text {presc }}$ were measured as follows (Frank et al., 2006): first, aerosol particles were brought to charge equilibrium with an X-ray source (TSI 3087). Then the DMA selected monodisperse particles of 10 different diameters in the size range of 23 to $321 \mathrm{~nm}$, which were passed on to the CCNC and the CPC (TSI 3762) measuring in parallel. At each diameter $(D)$, the CPC measured the number concentration of all aerosol particles $\left(N_{\mathrm{CN}}\right)$, and the $\mathrm{CCNC}$ measured the number concentration of $\mathrm{CCN}\left(N_{\mathrm{CCN}}\right)$ for the given supersaturation. The CCN efficiency spectrum is the size-resolved fraction of all activated particles as a function of $S_{\text {presc }}$. The recording of a CCN efficiency spectrum at a given $S_{\text {presc }}$ took $\sim 23 \mathrm{~min}$, including $\sim 90 \mathrm{~s}$ integration time for each measurement data point, $\sim 30$ s adjustment time for each new particle size, and $\sim 4$ min for adjustment to the next supersaturation level. The completion of a full measurement cycle comprising $\mathrm{CCN}$ efficiency spectra at five different supersaturation levels took $\sim 2 \mathrm{~h}$ (including additional $5 \mathrm{~min}$ of adjustment time between the highest and the lowest $S_{\text {presc }}$ level).

The measurement data of the $\mathrm{CCN}$ efficiency spectra were corrected for differences in the CCNC and CPC counting efficiencies as described in Rose et al. (2010), using a constant correction factor of 1.03. Moreover, a correction for multiply charged particles was performed according to Frank et al. (2006).

The supersaturation in the CCNC was calibrated using ammonium sulfate particles before, during, and after the campaign. We used the calibration method described in Rose et al. (2008), applying the activity parameterization Köhler model AP3 to derive the corresponding critical supersaturation from the critical dry diameter of $\mathrm{CCN}$ activation of the ammonium sulfate particles.

To relate the activation of aerosol particles in the CCNC to the activation at ambient conditions, the supersaturation levels prescribed in the CCNC at a sample temperature of approximately $298 \mathrm{~K}\left(S_{\text {presc }}\right)$ were scaled to an equivalent supersaturation at an average ambient air temperature during the cloud event of $\sim 273 \mathrm{~K}\left(S_{\mathrm{CCNC}}\right)$ as described in Appendix C.

\subsection{Error analysis}

During a cloud event the number concentration measured for large monodisperse interstitial aerosol particles is generally very low. Therefore the possible sources of errors are particularly important. One potential source of systematic errors is false counts of the instruments. However, during frequently performed zero filter tests, our instruments showed no false counts, so the systematic error initiated from false counts could be neglected. The random error of the particle concentration measured by the CCNC $\left(\Delta N_{\mathrm{CCN}}\right)$ and by the $\mathrm{CPC}\left(\Delta N_{\mathrm{CN}}\right)$, as well as the random error of the activated 
fraction $\left(\Delta\left(N_{\mathrm{CCN}} / N_{\mathrm{CN}}\right)\right)$ were derived through Gaussian error propagation.

Hence, the error of the activated fraction is given by

$$
\Delta\left(\frac{N_{\mathrm{CCN}}}{N_{\mathrm{CN}}}\right)=\sqrt{\left(\frac{\Delta N_{\mathrm{CCN}}}{N_{\mathrm{CN}}}\right)^{2}+\left(\frac{N_{\mathrm{CCN}} \cdot \Delta N_{\mathrm{CN}}}{N_{\mathrm{CN}}^{2}}\right)^{2}}
$$

in which $N_{\mathrm{CCN}}$ and $N_{\mathrm{CN}}$ are the concentrations per size bin measured during the integration interval by the CCNC and the CPC, respectively. The number concentration of particles is the number of measured particles $(c)$ divided by the sample volume: $N=c /(Q \cdot t)$, where $Q$ is the volumetric flow rate and $t$ is the integration time. From this, the errors of the particle concentrations $\left(\Delta N_{\mathrm{CCN}}\right.$ and $\left.\Delta N_{\mathrm{CN}}\right)$ are given by

$\Delta N=\sqrt{\left(\frac{\Delta c}{Q \cdot t}\right)^{2}+\left(\frac{c \cdot \Delta Q}{Q^{2} \cdot t}\right)^{2}+\left(\frac{c \cdot \Delta t}{Q \cdot t^{2}}\right)^{2}}$.

Note that for the volumetric flow rate in the CCNC we had to insert the value for the measured actual aerosol flow $\left(\sim 0.045 \mathrm{~L} \mathrm{~min}^{-1}\right)$ through the flow tube. This is only $1 / 11$ of the CCNC inlet flow since the inlet flow is split into a filtered sheath and an aerosol flow with a ratio of 10 . For the measurement time $t$ we used the integration time for $N_{\mathrm{CCN}}$ and $N_{\mathrm{CN}}$ at a given $D$ and $S_{\mathrm{CCNC}}(\sim 90 \mathrm{~s})$. The error of the flow rate $(\Delta Q)$ was the standard deviation of the mean aerosol flow rate (of the CCNC or CPC) during time $t$, and the error of the time $(\Delta t)$ we assumed to be $1 \mathrm{~s}$.

The error of the measured particle number $(c)$ we assumed to be the standard counting error of $c$ plus 1 because one particle is the smallest countable value of the CCNC and the CPC:

$\Delta c=\sqrt{c+1}$

The analysis showed that the error of the interstitial CCN to $\mathrm{CN}$ ratio $\left(N_{\mathrm{CCN}} / N_{\mathrm{CN}}\right)$ measured during a cloud event was rather large. The reason was the very small aerosol flow through the $\mathrm{CCNC}\left(\sim 0.045 \mathrm{~L} \mathrm{~min}^{-1}\right)$, which required relatively long integration times.

During out-of-cloud conditions we have not encountered problems with counting statistics since the particle concentrations per size bin were at least 1 order of magnitude higher than during in-cloud conditions. We conclude that, in future studies measuring the size-resolved $\mathrm{CCN}$ fraction of interstitial particles in a cloud, it is necessary to increase the actual measured number of particles either by measuring over a longer time interval or by increasing the aerosol flow through the $\mathrm{CCNC}$.

\subsection{Calculation of $\mathrm{CCN}$ size distribution and integral CCN efficiency}

Parallel to the CCN measurements, a scanning mobility particle sizer (SMPS, TSI 3080, using a DMA 3081, a CPC
3025A, and a neutralizer 3087 - operating with standard TSI software) was operated to measure the aerosol particle number $(\mathrm{CN})$ size distribution over the size range of 16 to $600 \mathrm{~nm}$ (26 logarithmically equidistant size bins). Integral $\mathrm{CN}$ concentrations, $N_{\mathrm{CN} \text {,int }}$, were calculated by integrating the $\mathrm{CN}$ size distributions.

CCN size distributions were calculated by multiplying the best-fit cumulative Gaussian distribution function (cf. Rose et al., 2008) of CCN efficiency spectra with the respective total aerosol size distributions, which were interpolated on a grid of 250 size steps (Rose et al., 2010). Integral CCN concentrations, $N_{\mathrm{CCN} \text {,int }}$, were calculated by integrating the $\mathrm{CCN}$ size distributions. Integral $\mathrm{CCN}$ efficiencies $\left(N_{\mathrm{CCN} \text {,int }} / N_{\mathrm{CN} \text {,int }}\right)$ were calculated as the ratio of integral $\mathrm{CCN}$ concentration at a certain $S_{\mathrm{CCNC}}$ to integral CN concentration.

A list of frequently used symbols is given in Table A1 at the end of the manuscript.

\section{Results and discussion}

\subsection{Derivation of cloud supersaturation from $\mathrm{CCN}$ measurements (CCNC method)}

\subsubsection{Lower bound of peak supersaturation based on CCN efficiency spectra, $S_{\text {low }}$ (CCNC)}

Figure 2 shows the size-resolved CCN efficiency spectra measured at five different supersaturation levels $\left(S_{\mathrm{CCNC}}\right)$ for interstitial aerosol particles in cloud (red data points) and for total aerosol particles out of cloud (grey lines).

Out of cloud, the measured CCN efficiencies $\left(N_{\mathrm{CCN}} / N_{\mathrm{CN}}\right)$ exhibited the expected $\mathrm{S}$-shaped increase from 0 for small particles to about 1 for large particles. The midpoint activation diameter $\left(D_{\mathrm{a}}\right.$, at $\left.N_{\mathrm{CCN}} / N_{\mathrm{CN}}=0.5\right)$ can be regarded as the average critical diameter of $\mathrm{CCN}$ activation at the given supersaturation. As expected, $D_{\mathrm{a}}$ exhibited a gradual decrease with increasing $S_{\mathrm{CCNC}}$, i.e., the threshold diameter for the $\mathrm{CCN}$ activation of aerosol particles is lower for higher supersaturation.

In cloud, the CCN efficiency spectra of the interstitial aerosol observed at medium to high supersaturations were similar to those observed out of cloud ( $S_{\mathrm{CCNC}} \geq 0.25 \%$, Fig. 2c-e). At low supersaturations, however, they looked very different, and the $\mathrm{CCN}$ efficiency of the interstitial aerosol particles remained close to zero throughout the investigated diameter range $\left(S_{\mathrm{CCNC}}=0.07\right.$ and $0.13 \%$, Fig. $2 \mathrm{a}$ and $\mathrm{b}$ ).

From this difference we derive a lower bound for the peak supersaturation at which particles have been activated to cloud droplets $\left(S_{\text {low }}\right)$. We take $S_{\text {low }}(C C N C)$ to be the mean value between the highest $S_{\mathrm{CCNC}}$ level at which no significant activation of interstitial particles is observed $\left(\left(N_{\mathrm{CCN}} / N_{\mathrm{CN}}-\right.\right.$ statistical error $\left.) \leq 0\right)$ and the lowest $S_{\mathrm{CCNC}}$ level at which significant activation of 

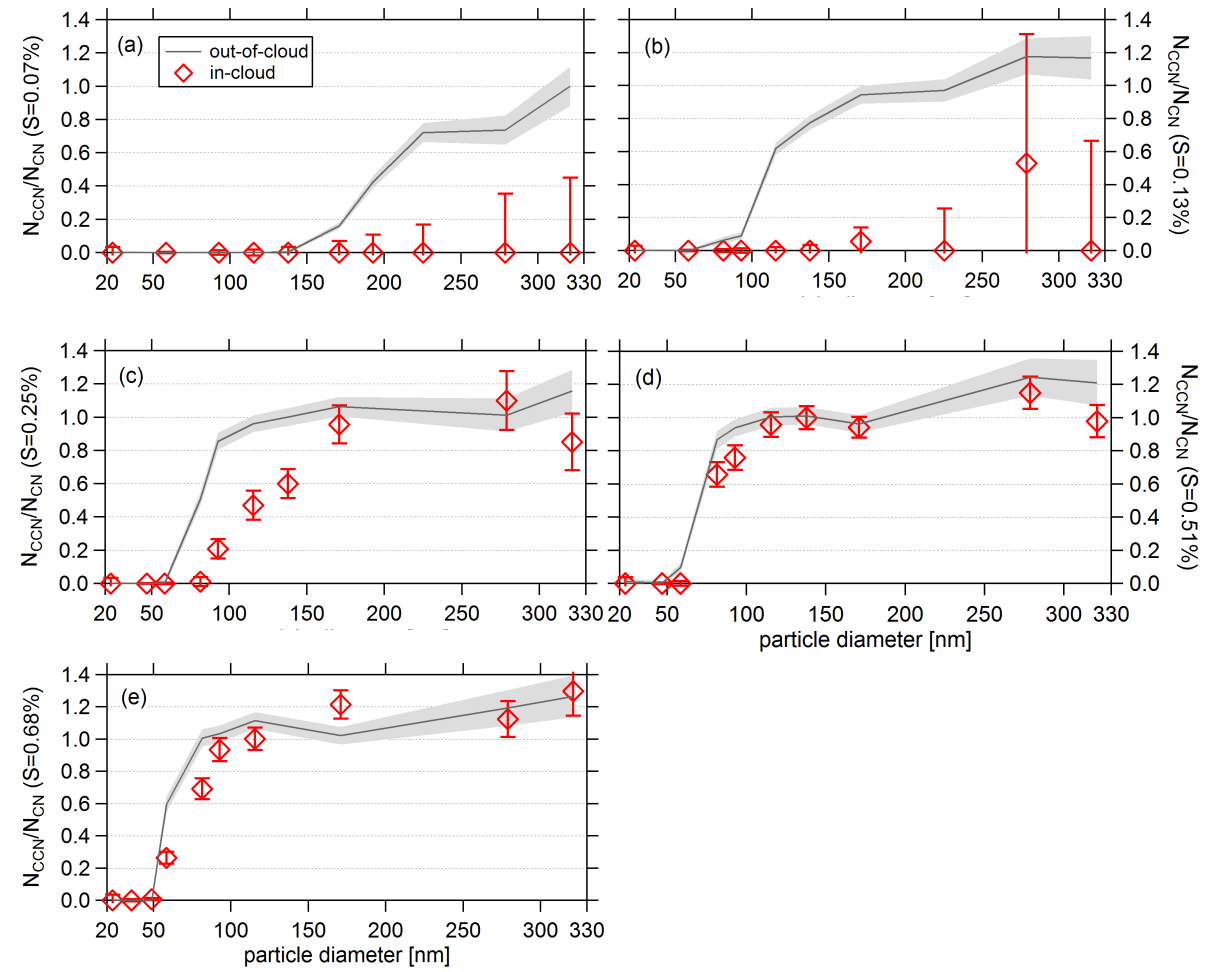

Figure 2. Size-resolved CCN efficiency spectra measured for different $S_{\mathrm{CCNC}}$. The red squares represent one example measurement during the cloud event (19 September 2012, 15:26-17:17 UTC) and the error bars correspond to the individual statistical errors calculated as described in Sect. 2.5. The grey shaded area represents the range of the measured data points \pm statistical error for one example CCN measurement performed during out-of-cloud conditions (20 September 2012, 02:54-04:47 UTC).

interstitial particles is observed $\left(\left(N_{\mathrm{CCN}} / N_{\mathrm{CN}}-\right.\right.$ statistical error) $>0)$. For the investigated cloud, we thus obtained $S_{\text {low }}(\mathrm{CCNC})=0.19 \pm 0.06 \% \quad$ (arithmetic mean \pm standard deviation). Particles exhibiting critical supersaturations smaller than or equal to $S_{\text {low }}(\mathrm{CCNC})$ had formed cloud droplets and were therefore not sampled by the interstitial inlet. Hence, we did not measure activated particles in the $\mathrm{CCNC}$ as long as $S_{\mathrm{CCNC}} \leq S_{\text {low }}$ (CCNC). Interstitial particles could be activated in the CCNC only if $S_{\mathrm{CCNC}}$ exceeded $S_{\text {low }}(\mathrm{CCNC})$.

Figure 3 displays integral $\mathrm{CCN}$ efficiencies $\left(N_{\mathrm{CCN} \text {,int }} / N_{\mathrm{CN} \text {,int }}\right)$ plotted against water vapor supersaturation. It shows that $S_{\text {low }}(\mathrm{CCNC})$ can be derived not only from size-resolved measurement data but also from integral measurements of $\mathrm{CCN}$ and $\mathrm{CN}$ concentrations using a combination of CCNC and CPC without DMA. In fact, even a stand-alone CCNC instrument and plot of $N_{\mathrm{CCN} \text {,int }}$ vs. $S_{\mathrm{CCNC}}$ would suffice for the determination of $S_{\text {low }}$, provided that counting statistics are properly taken into account. The definition of $S_{\text {low }}$ is the same as for the size-resolved CCN measurements: $S_{\text {low }}(\mathrm{CCNC})$ is the mean value between the highest $S_{\mathrm{CCNC}}$ level at which no significant activation of interstitial particles is observed and the lowest $S_{\mathrm{CCNC}}$ level at which significant activation of interstitial particles is observed.

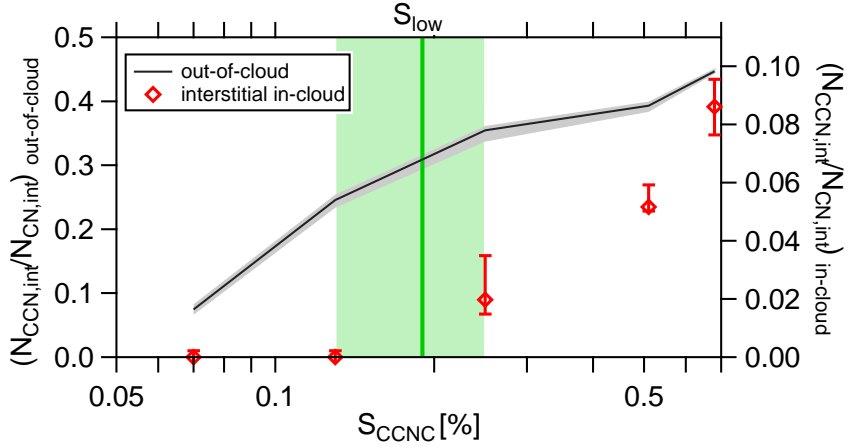

Figure 3. Integral CCN efficiency measured for total aerosol during out-of-cloud conditions (grey shaded area, range of measured data points \pm statistical error) and for interstitial aerosol in one example measurement during in-cloud conditions (red data points; error bars correspond to the individual statistical errors) plotted as a function of $S_{\mathrm{CCNC}}$. The measurement times are the same as in Fig. 2. The vertical green line and shaded area represent the arithmetic mean and standard deviation range of $S_{\text {low }}(\mathrm{CCNC})$. Since the activated fraction is much lower for in-cloud conditions, $N_{\mathrm{CCN} \text {,int }}$ is illustrated on the right axis with a smaller scale. 


\subsubsection{Average peak supersaturation based on $\mathrm{CCN}$ size distributions, $S_{\text {avg }}(\mathrm{CCNC})$}

The effective average peak supersaturation $\left(S_{\text {avg }}\right)$, at which the activation curve at the CCNC represents the activation that happened in the cloud event, can best be derived by comparison of the $\mathrm{CCN}$ size distributions measured for total aerosol at different supersaturation levels with the size distribution of aerosol particles actually activated in the cloud. The number size distribution of activated particles in a cloud is given by the difference between the size distributions of total and interstitial aerosol. In principle, the particle fraction activated at a given supersaturation in the cloud should also be activated at an equivalent supersaturation level in the CCNC instrument, taking into account the influence of different ambient conditions (in particular the influence of temperature on the Kelvin effect as described in Appendix C). Consequently, the number size distribution of activated particles in a cloud should be approximately equal to the $\mathrm{CCN}$ size distribution measured with the CCNC for total aerosol at a supersaturation level equivalent to the effective average peak supersaturation in the cloud.

In this study we had no opportunity to measure total aerosol properties under in-cloud conditions. For the investigated cloud event, however, the in-cloud and out-of-cloud measurement periods immediately followed each other without apparent changes in the regional atmospheric conditions. Thus, we assumed the total aerosol properties measured out of cloud to be approximately representative of the total aerosol properties in cloud.

Figure 4 shows aerosol particle size distributions measured by SMPS during the investigated cloud event on 19 September 2012. For the total aerosol out of cloud, we observed a bimodal distribution with a minimum at $\sim 60 \mathrm{~nm}$. The Aitken and accumulation mode peaked at $\sim 34 \mathrm{~nm}$ with a maximum of $\sim 2000 \mathrm{~cm}^{-3}(\mathrm{~d} N / \mathrm{d} \log D)$ and at $\sim 124 \mathrm{~nm}$ with a maximum of $\sim 1000 \mathrm{~cm}^{-3}(\mathrm{~d} N / \mathrm{d} \log D)$, respectively. For the interstitial aerosol in cloud, the Aitken mode was only slightly shifted with a maximum of $\sim 2200 \mathrm{~cm}^{-3}(\mathrm{~d} N / \operatorname{dlog} D)$ at $\sim 29 \mathrm{~nm}$, whereas the accumulation mode almost disappeared because most of the larger particles had been activated into cloud droplets and could therefore not be sampled by the interstitial inlet. Figure 5 shows the size distribution of aerosol particles activated in the cloud in comparison to CCN size distributions at $S_{\mathrm{CCNC}}=0.25,0.51$ and $0.68 \%$. The size distribution of aerosol particles activated in the cloud was calculated by subtraction of the interstitial aerosol size distribution measured in cloud from the total aerosol size distribution measured out of cloud. The number size distribution of activated particles exhibited a large peak at $\sim 124 \mathrm{~nm}$ with a maximum of $\sim 1000 \mathrm{~cm}^{-3}(\mathrm{~d} N / \operatorname{dlog} D)$ and a shoulder at $\sim 40 \mathrm{~nm}$ with $\sim 350 \mathrm{~cm}^{-3}(\mathrm{~d} N / \operatorname{dlog} D)$, whereby the shoulder is mainly in the range of the error bars. On the one hand, the shoulder may result from a slight shift of the $\mathrm{CN}$ size distribution between in-cloud and out-of-cloud conditions,

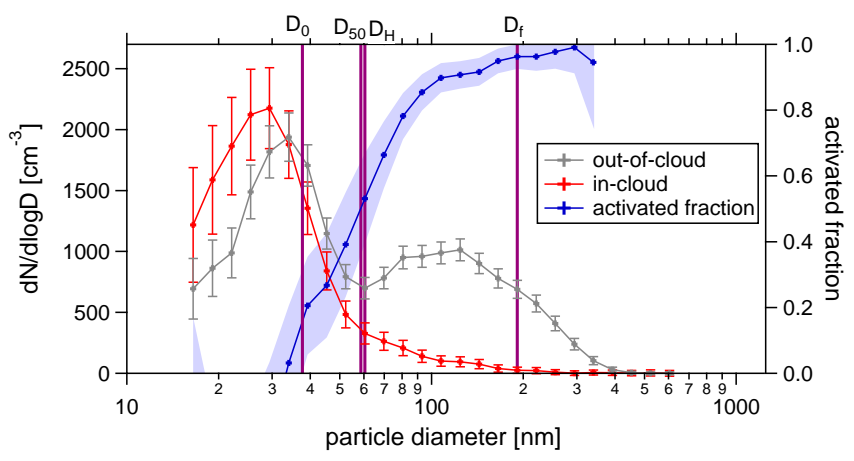

Figure 4. Average number size distribution of total aerosol particles (grey crosses, out of cloud) and of interstitial aerosol particles (red crosses, in cloud). The error bars correspond to the individual statistical errors calculated as described in Sect. 2.5. The activated fraction (blue crosses represent grey minus red, divided by grey; shaded area is the range of the statistical error of the data points) is plotted on the right axis. To assure comparability of the size distributions, their averaging times were chosen to be unambiguous with respect to $\mathrm{LWC}$ for in-cloud (mean $\mathrm{LWC}=0.089 \mathrm{~g} \mathrm{~m}^{-3}$ ) and out-of-cloud conditions (mean $\mathrm{LWC}=0.016 \mathrm{~g} \mathrm{~m}^{-3}$ ) within a short time interval (in cloud: 19 September 2012, 15:26-16:25 UTC; out of cloud: 19 September 2012, 17:30-18:00 UTC). The vertical lines indicate the diameters of zero activation $\left(D_{0}\right), 50 \%$ activation $\left(D_{50}\right)$, Hoppel minimum $\left(D_{\mathrm{H}}\right)$, and full activation $\left(D_{\mathrm{f}}\right)$.

which is likely due to aging processes such as condensational growth or coagulation, which are usually more pronounced for the Aitken mode than for the accumulation mode. On the other hand, it may result from a locally higher supersaturation during the cloud event ( $\left.S_{\text {high }}\right)$.

As shown in Fig. 5, the right-hand side of the size distribution of activated particles $(D>100 \mathrm{~nm})$ is in good agreement with each of the displayed CCN size distributions. In the diameter range of 34-120 nm, however, the CCN size distribution at $S_{\mathrm{CCNC}}=0.25 \%$ is much lower, with an average relative deviation of the error bars of about $9.0 \%$. The CCN size distribution at $S_{\mathrm{CCNC}}=0.51 \%$ provides a fairly good match (average relative deviation $6.3 \%$ ), and the deviation at $S_{\mathrm{CCNC}}=0.68 \%$ is only slightly higher (average relative deviation $6.8 \%$ ). Thus, we take $S_{\text {avg }}(\mathrm{CCNC}) \approx 0.51 \pm 0.06 \%$ as an estimate for the effective average peak supersaturation around which most particles had been activated and most cloud droplets had been formed.

\subsection{Derivation of cloud supersaturation from SMPS measurements (SMPS method)}

\subsubsection{Average peak supersaturation based on $50 \%$ activation, $S_{\text {avg }}\left(D_{50}, \kappa\right)$}

A common approach to derive an effective average peak supersaturation at which ambient clouds are formed is to compare the particle number or $\mathrm{CN}$ size distributions of total and interstitial aerosol (e.g., Anttila et al., 2009; Asmi et 


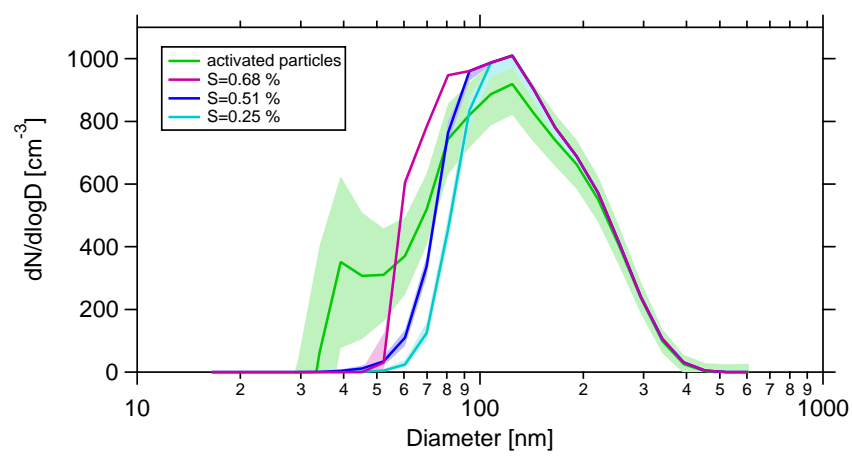

Figure 5. Average number size distribution of activated particles in the cloud (green) and CCN size distributions at $S_{\mathrm{CCNC}}=0.25$, 0.51 , and $0.68 \%$ (magenta, blue, and cyan). The shaded areas represent the range of the statistical error of the individual data points.

al., 2012; Ditas et al., 2012; Hammer et al., 2014). We also used this method, which will be referred to as the "SMPS method", to calculate $S_{\text {avg }}$ from our aerosol size distribution measurement results.

In our study it was not possible to measure the particle size distribution of both interstitial and total aerosol inside the investigated cloud. As outlined above, however, we have good reasons to assume that the total aerosol size distribution measured out of cloud was approximately representative of the total aerosol in cloud. A crucial point of the SMPS method is that it builds on Köhler theory calculations and requires an assumption on the hygroscopicity of the activated particles, which depends on their chemical composition. Appendix B describes how the hygroscopicity parameter, $\kappa$, relates the dry activation diameter of an aerosol particle to its critical supersaturation, which is the minimum supersaturation required to form a stable cloud droplet.

Figure 4 shows the $\mathrm{CN}$ size distribution of interstitial aerosol (red, in cloud) and total aerosol (grey, out of cloud). The activated fraction (blue) was calculated by dividing the number size distribution of activated particles (out of cloud minus in cloud) by the $\mathrm{CN}$ size distribution of the total aerosol. The diameter at which the activated fraction reached a value of $50 \%, D_{50}=59 \mathrm{~nm}$, can be regarded as an effective critical dry diameter of particle activation in the cloud. By Köhler theory this diameter can be converted into a critical supersaturation, which in turn can be regarded as an effective average peak supersaturation of the cloud (Hammer et al., 2014).

As mentioned above, the Köhler theory calculations require specific knowledge or assumptions about the hygroscopicity of the aerosol particles. Thus, we tested a range of relevant hygroscopicity parameters $(\kappa)$ as specified in Appendices A and B and Table 1: (1) $\kappa_{\mathrm{a}}$ as determined from the measured $\mathrm{CCN}$ efficiency spectra during out-of-cloud conditions $\left(\kappa_{\mathrm{a}}=0.19\right),(2) \kappa_{\text {cut }}$ as determined from the observed total $\mathrm{CCN}$ concentration and the $\mathrm{CN}$ size distribution
Table 1. Different combinations of hygroscopicity parameters $\left(\kappa_{\mathrm{a}}, \kappa_{\text {cut }}, \kappa_{\text {mean }}, \kappa_{\mathrm{AMS}}\right)$ and activation threshold diameters $\left(D_{\mathrm{f}}\right.$, $\left.D_{50}, D_{\mathrm{H}}, D_{0}\right)$ used to determine the cloud peak supersaturations reported in Table 2 by Köhler theory calculations as detailed in Appendices $\mathrm{A}$ and $\mathrm{B}$.

\begin{tabular}{lrrrr}
\hline & $D_{\mathrm{f}}=191 \mathrm{~nm}$ & $D_{50}=59 \mathrm{~nm}$ & $D_{\mathrm{H}}=60 \mathrm{~nm}$ & $D_{0}=38 \mathrm{~nm}$ \\
\hline$\kappa_{\mathrm{a}}$ & 0.51 & 0.19 & 0.19 & 0.19 \\
$\kappa_{\text {cut }}$ & 0.48 & 0.20 & 0.20 & 0.20 \\
$\kappa_{\text {mean }}$ & 0.3 & 0.3 & 0.3 & 0.3 \\
$\kappa_{\text {AMS }}$ & 0.45 & 0.45 & 0.45 & 0.45 \\
\hline
\end{tabular}

during out-of-cloud conditions ( $\kappa_{\text {cut }}=0.20$ ), (3) a global average $\kappa$ value for continental aerosol of $\kappa_{\text {mean }}=0.3$ (Pringle et al., 2010), and (4) $\kappa_{\mathrm{AMS}}$ as derived from the aerosol chemical composition $\left(\kappa_{\mathrm{AMS}}=0.45\right)$. The large difference between $\kappa_{\text {AMS }}$ and $\kappa_{\mathrm{a}}$ or $\kappa_{\text {cut }}$ can be attributed to a size dependence of particle hygroscopicity with an enhanced organic mass fraction for sub- $100 \mathrm{~nm}$ particles, as observed in earlier studies (e.g., Gunthe et al., 2009, 2011; Rose et al., 2011). The parameter $\kappa_{\text {AMS }}$ reflects the mass-weighted average hygroscopicity of the total aerosol, which is dominated by large accumulation-mode particles with an enhanced inorganic fraction (typically around $300 \mathrm{~nm}$ ). Depending on the prescribed $\kappa$ value, the effective average peak supersaturation derived from the SMPS-based activation curve, $S_{\mathrm{avg}}\left(D_{50}, \kappa\right)$, was calculated to be in the range of 0.44 to $0.68 \%$ (arithmetic mean \pm standard deviation $0.58 \pm 0.10$, Table 2). This range is in agreement with the estimate derived above from the $\mathrm{CCN}$ measurement data without any assumption on particle hygroscopicity: $S_{\text {avg }}(\mathrm{CCNC}) \approx 0.51 \pm 0.06 \%$ (Sect. 3.1.2).

\subsubsection{Average peak supersaturation based on the Hoppel minimum, $S_{\text {avg }}\left(D_{\mathrm{H}} \kappa\right)$}

An earlier approach by Hoppel et al. (1996) derived the average cloud peak supersaturation from the shape of the aerosol size distributions typically observed in remote marine boundary layer air. The authors proposed that the double-peaked structure of the aerosol size distribution is the result of particle processing through nonprecipitating cloud cycles. Thus, the diameter at which the minimum in a double-peaked particle number size distribution of total aerosol occurs ("Hoppel minimum") can be regarded as an average critical diameter of particle activation related to the average cloud peak supersaturation.

As shown in Fig. 4, the total aerosol size distribution observed out of cloud exhibited a very pronounced doublepeak structure with a minimum at $D_{\mathrm{H}}=60 \mathrm{~nm}$. As described above (Sect. 3.2.1) and in Appendix B, we performed Köhler theory calculations to also convert $D_{\mathrm{H}}$ into a critical supersaturation that can be regarded as an effective average cloud peak supersaturation, assuming appropriate hygroscopicity parameter values (Table 1). 
Table 2. Lower bounds, average values, and upper bounds of cloud peak supersaturation $\left(S_{\text {low }}, S_{\text {avg }}, S_{\text {high }}\right)$ obtained by Köhler theory calculations assuming different types of hygroscopicity parameter $\left(\kappa_{\mathrm{a}}, \kappa_{\text {cut }}, \kappa_{\text {mean }}, \kappa_{\text {AMS }}\right)$ as reported in Table 1 (SMPS method, Sect. 3.2). The values displayed in the second-last line represent the arithmetic mean \pm standard deviation of the preceding four lines (SMPS method average). The supersaturation values displayed in the last line were obtained without assumptions about particle hygroscopicity (arithmetic mean \pm standard deviation; CCNC method, Sect. 3.1).

\begin{tabular}{lrrrr}
\hline & $\begin{array}{r}S_{\text {low }}\left(D=D_{\mathrm{f}}, \kappa\right) \\
{[\%]}\end{array}$ & $\begin{array}{r}S_{\text {avg }}\left(D=D_{50}, \kappa\right) \\
{[\%]}\end{array}$ & $\begin{array}{r}S_{\text {avg }}\left(D=D_{\mathrm{H}}, \kappa\right) \\
{[\%]}\end{array}$ & $\begin{array}{r}S_{\text {high }}\left(D=D_{0}, \kappa\right) \\
{[\%]}\end{array}$ \\
\hline$S\left(D, \kappa=\kappa_{\mathrm{a}}\right)$ & 0.07 & 0.68 & 0.65 & 1.31 \\
$S\left(D, \kappa=\kappa_{\text {cut }}\right)$ & 0.07 & 0.66 & 0.63 & 1.28 \\
$S\left(D, \kappa=\kappa_{\text {mean }}\right)$ & 0.09 & 0.54 & 0.52 & 1.05 \\
$S\left(D, \kappa=\kappa_{\text {AMS }}\right)$ & 0.08 & 0.44 & 0.42 & 0.86 \\
$S$ (SMPS $)$ & $0.08 \pm 0.008$ & $0.58 \pm 0.10$ & $0.56 \pm 0.09$ & $1.13 \pm 0.18$ \\
$S$ (CCNC) & $0.19 \pm 0.06$ & $0.51 \pm 0.06$ & $0.51 \pm 0.06$ & - \\
\hline
\end{tabular}

Depending on the prescribed $\kappa$ value, the effective average peak supersaturation derived from the Hoppel minimum diameter, $S_{\text {avg }}\left(D_{\mathrm{H}}, \kappa\right)$, was calculated to be in the range of 0.42 to $0.65 \%$ (arithmetic mean \pm standard deviation: $0.56 \pm 0.09 \%$; Table 2). This range is again in agreement with the estimate derived from the $\mathrm{CCN}$ measurement data $\left(S_{\text {avg }}(\mathrm{CCNC}) \approx 0.51 \pm 0.06 \%\right.$, Sect. 3.1.2).

\subsubsection{Lower bound of peak supersaturation based on full activation, $S_{\text {low }}\left(D_{\mathrm{f}}, \kappa\right)$}

To derive a lower bound of cloud peak supersaturation, $S_{\text {low }}$, from the activated particle fraction based on aerosol size distribution data, we determine an effective threshold diameter of full activation $\left(D_{\mathrm{f}}\right)$. For $D_{\mathrm{f}}$ we take the mean value between the largest diameter at which the activated fraction is significantly below unity ((activated fraction + statistical error $)<1$ ) and the smallest diameter at which practically full activation is observed ((activated fraction + statistical error) $\geq 1$ ). From Fig. 4 (blue data points) we obtained $D_{\mathrm{f}}=191 \mathrm{~nm}$. As described above and in Appendix B, we performed Köhler theory calculations to also convert $D_{\mathrm{f}}$ into a critical supersaturation, which can be regarded as a lower bound of cloud peak supersaturation, assuming relevant hygroscopicity parameter values (Table 1$)$. Depending on the prescribed $\kappa$ values, $S_{\text {low }}\left(D_{\mathrm{f}}, \kappa\right)$ was calculated to be between 0.07 and $0.09 \%$ (arithmetic mean \pm standard deviation: $0.08 \pm 0.008 \%$; Table 2). This range disagrees with the estimate derived from the $\mathrm{CCN}$ approach $\left(S_{\text {low }}\right.$ $(\mathrm{CCNC})=0.19 \pm 0.06 \%)$. A reason could be that the definition of $S_{\text {low }}$ from the SMPS method strongly depends on uncertainties of the SMPS measurement. On the other hand, the SMPS approach tells more about the cloud history and not about the actual supersaturation at the inlet, which is accessible by the CCNC method. Therefore, the discrepancy can be traced back to the fact that SMPS and CCNC methods measure the supersaturation reached in the air parcel at different times in its history.

\subsubsection{Upper bound of peak supersaturation based on zero activated fraction, $S_{\text {high }}\left(D_{0}, \kappa\right)$}

To derive an upper bound of cloud peak supersaturation, $S_{\text {high }}$, from the activated particle fraction based on aerosol size distribution data, we determine an effective threshold diameter of zero activation $\left(D_{0}\right)$. For $D_{0}$ we take the mean value between the largest diameter at which no significant activation is observed ((activated fraction - statistical error $) \leq 0$ ) and the smallest diameter at which the activated fraction is significantly above zero ((activated fraction - statistical error) $>0$ ). From Fig. 4 (blue data points) we obtained $D_{0}=38 \mathrm{~nm}$. As described above and in Appendix B, we performed Köhler theory calculations to also convert $D_{0}$ into a critical supersaturation that can be regarded as an upper bound of cloud peak supersaturation, assuming relevant hygroscopicity parameter values (Table 1 ). Depending on the prescribed $\kappa$ values, $S_{\text {high }}\left(D_{0}, \kappa\right)$ was calculated to be between 0.86 and $1.31 \%$ (arithmetic mean \pm standard deviation: $1.13 \pm 0.18 \%$; Table 2).

\section{Conclusions and outlook}

In this study we showed how size-resolved measurements of aerosol particles and $\mathrm{CCN}$ in cloud and out of cloud can be used to derive effective average values as well as lower and upper bounds of cloud peak supersaturation. For the investigated cloud event, the different estimates of the average peak supersaturation $\left(S_{\text {avg }}\right)$ obtained from CCNC and SMPS measurement data of total and interstitial aerosol particles are largely consistent with each other (Table 2). The main goal of this study, however, is to present an alternative method to estimate the cloud supersaturation. Thus, the numbers that we obtained for $S_{\text {cloud }}$ are not necessarily generally representative values.

The lower bound of cloud peak supersaturation $\left(S_{\text {low }}\right)$ calculated by the CCNC method is significantly higher than the $S_{\text {low }}$ calculated by the SMPS method. The following two 
effects may explain this discrepancy: (i) SMPS data analysis requires integration over a certain time period to reduce uncertainties. This has an influence on the error, which is particularly important for the $S_{\text {low }}$ estimation. (ii) All supersaturation estimates based on the SMPS method reflect the full history of supersaturation experienced by the aerosol particles during cloud evolution. Thus, particles that have been activated once into cloud droplets will be counted, independent of the time when the activation actually occurred. In contrast, the CCNC method, in which particle activation takes place during the measurements, provides in situ measurements of the actual supersaturation in the probed cloud air parcel.

The uncertainties of the estimates of cloud peak supersaturation presented here are mostly due to limitations in the time resolution and counting statistics of the measurement devices used (CCNC, CPC, SMPS). Estimates derived from SMPS data only are also influenced by uncertainties in the determination or assumption of aerosol hygroscopicity parameters.

In future studies, some uncertainties can and should be reduced by optimizing the applied instrumentation and measurement procedures. Specific avenues for improvement are as follows:
1. Parallel operation of total and interstitial aerosol inlets and SMPS measurements will make the determination of the fraction of aerosol particles activated in cloud more reliable.

2. Parallel operation of multiple CCNCs at different supersaturation levels and/or faster scanning of supersaturation in the CCNC by varying the flow rate rather than the temperature gradient (Moore and Nenes, 2009) will increase the number of supersaturation levels that can be monitored and hence will increase the precision of the derived cloud peak supersaturations.

3. Increasing the aerosol-to-sheath flow ratio and/or the integration times of the CCNC and SMPS will help to improve the counting statistics.

We suggest that comprehensive measurements of the temporal and spatial variability of cloud peak supersaturation (average values as well as upper and lower bounds) may provide deeper insights into the evolution of clouds, including the interaction of aerosol and cloud particles, water vapor, and dynamical features like turbulence and entrainment. 


\section{Appendix A: calculation of $\kappa$ from AMS measurements}

During the ACRIDICON-Zugspitze campaign the chemical composition of submicron aerosol particles was measured with a C-ToF-AMS (compact time-of-flight aerosol mass spectrometer; Drewnick et al., 2005; Canagaratna et al., 2007). The C-ToF-AMS quantitatively determines the mass concentration of nonrefractory species like organics, sulfate, nitrate, ammonium, and chloride. For the analysis of the cloud event investigated in this study, the AMS mass concentrations were averaged over the time period of outof-cloud conditions (19 September 2013, 19:56-20:43 UTC). The organic $\left(f_{\text {org }}\right)$ and inorganic mass fractions $\left(f_{\text {inorg }}\right)$ were calculated by dividing the organic and inorganic (sum of sulfate, nitrate, ammonium, and chloride) mass concentrations by the sum of the masses of all AMS measured components, respectively.
To describe the influence of chemical composition on the CCN activity of aerosol particles, Petters and Kreidenweis (2007) proposed to use the hygroscopicity parameter $\kappa$. The hygroscopicity parameter ( $\left.\kappa_{\mathrm{AMS}}\right)$ was approximated from the AMS obtained mass fraction by a simple mixing rule as follows:

$\kappa_{\mathrm{AMS}}=f_{\text {org }} \cdot \kappa_{\text {org }}+f_{\text {inorg }} \cdot \kappa_{\text {inorg }}$,

in which $\kappa_{\text {org }}$ and $\kappa_{\text {inorg }}$ are the hygroscopicity parameters for pure organic and inorganic substances $\left(\kappa_{\text {org }}=0.1\right.$ and $\left.\kappa_{\text {inorg }}=0.6\right)$ (Gunthe et al., 2009; Dusek et al., 2010; Rose et al., 2011). For the average AMS-derived hygroscopicity parameter we obtained $\kappa_{\mathrm{AMS}}=0.45$. This value reflects the mass-weighted average hygroscopicity of the total aerosol, which is dominated by large accumulationmode particles with an enhanced inorganic fraction (typically around $300 \mathrm{~nm}$ ).

Table A1. Notation (frequently used symbols).

\begin{tabular}{ll}
\hline Symbol & Quantity, unit \\
\hline$N_{\mathrm{CCN}}$ & monodisperse number concentration of cloud condensation nuclei $(\mathrm{CCN}), \mathrm{cm}^{-3}$ \\
$N_{\mathrm{CN}}$ & monodisperse number concentration of condensation nuclei $(\mathrm{CN}), \mathrm{cm}^{-3}$ \\
$N_{\mathrm{CCN}} / N_{\mathrm{CN}}$ & CCN efficiency (size resolved) \\
$N_{\mathrm{CCN}, \text { int }}$ & integral CCN concentration, $\mathrm{cm}^{-3}$ \\
$N_{\mathrm{CN}, \text { int }}$ & integral CN concentration, $\mathrm{cm}^{-3}$ \\
$N_{\mathrm{CCN}, \text { int }} / N_{\mathrm{CCN}, \text { int }}$ & integral CCN efficiency \\
$S_{\mathrm{presc}}$ & water vapor supersaturation prescribed in the CCNC operated at room temperature $(\sim 298 \mathrm{~K}), \%$ \\
$S_{\mathrm{CCNC}}$ & water vapor supersaturation in the CCNC scaled to cloud temperature $(\sim 273 \mathrm{~K}), \%$ \\
$S_{\text {low }}$ & lower bound of cloud peak supersaturation, $\%$ \\
$S_{\mathrm{avg}}$ & average value of cloud peak supersaturation, $\%$ \\
$S_{\mathrm{high}}$ & upper bound of cloud peak supersaturation, $\%$ \\
$D_{0}$ & diameter of zero activation observed in the cloud, nm \\
$D_{50}$ & diameter of $50 \%$ activation observed in the cloud, nm \\
$D_{\mathrm{H}}$ & diameter of the Hoppel minimum, nm \\
$D_{\mathrm{f}}$ & diameter of full activation observed in the cloud, nm \\
$D_{\mathrm{a}}$ & midpoint activation diameter of CCN efficiency spectra (at $\left.N_{\mathrm{CCN}} / N_{\mathrm{CN}}=0.5\right), \mathrm{nm}$ \\
$D_{\text {cut }}$ & cut-off diameter of CCN activation, nm \\
$\kappa$ & effective hygroscopicity parameter \\
$\kappa_{\mathrm{a}}$ & hygroscopicity parameter derived from $D_{\mathrm{a}}$ via Köhler theory \\
$\kappa_{\text {cut }}$ & hygroscopicity parameter derived from $D_{\text {cut }}$ via Köhler theory \\
$\kappa_{\text {mean }}$ & mean hygroscopicity parameter for continental aerosol $\left(\kappa_{\text {mean }}=0.3\right)$ \\
$\kappa_{\mathrm{AMS}}$ & hygroscopicity parameter derived from AMS data $(\kappa$ AMS $=0.45)$ \\
\hline &
\end{tabular}




\section{Appendix B: calculation of $\boldsymbol{\kappa}$ from CCN measurements and Köhler theory}

The Köhler theory relates the dry diameter of an aerosol particle to its critical water vapor supersaturation, i.e., to the minimum supersaturation that is required to form a stable cloud droplet (Köhler, 1936). The following $\kappa$-Köhler equation (equivalent to Eq. (6) of Petters and Kreidenweis, 2007) enables calculation of the critical supersaturation $\left(S_{\text {crit }}\right)$ for a given pair of dry particle diameters, $D$, and hygroscopicity parameters, $\kappa$, or the $\kappa$ parameter for a given pair of critical supersaturations and activation diameters:

$S=\left(\frac{D_{\text {wet }}^{3}-D^{3}}{D_{\text {wet }}^{3}-D^{3}(1-\kappa)} \exp \left(\frac{4 \sigma M_{\mathrm{w}}}{R T \rho_{\mathrm{w}} D_{\text {wet }}}\right)-1\right) \cdot 100 \%$,

where $D_{\text {wet }}$ is the diameter of the droplet, $\sigma$ is the surface tension of the droplet (approximated by that of water, $\left.\sigma=0.072 \mathrm{~J} \mathrm{~m}^{-2}\right), M_{\mathrm{w}}$ is the molar mass of water $\left(M_{\mathrm{w}}=\right.$ $\left.0.018015 \mathrm{~kg} \mathrm{~mol}^{-1}\right), R$ is the universal gas constant $(R=$ $\left.8.315 \mathrm{~J} \mathrm{~K}^{-1} \mathrm{~mol}^{-1}\right)$, and $\rho_{\mathrm{w}}$ is the density of water $\left(\rho_{\mathrm{w}}=\right.$ $997.1 \mathrm{~kg} \mathrm{~m}^{-3}$ ).

In this study, two approaches were tested to derive $\kappa$ from the CCN measurement results. Firstly, the hygroscopicity parameter $\kappa$ was determined from Eq. (B1) by inserting the activation diameter $D_{\text {a }}$ (Sect. 3.1.1) derived from the CCN efficiency spectra measured out of cloud (Fig. 1) for $D$ and varying both $\kappa$ and the droplet diameter $D_{\text {wet }}$ until $S$ was at the same time equal to the prescribed supersaturation $S_{\text {presc }}$ and to the maximum of Eq. (B1) (cf. Rose et al., 2010). The temperature, $T$, used in Eq. (B1) was set to the value at which the particles were activated in the CCN $(\sim 298 \mathrm{~K})$.

A range of $\kappa_{\mathrm{a}}$ values between 0.14 and 0.59 were obtained for the different combinations of $S_{\text {presc }}$ and $D_{\text {a }}$ (highest values for low $S_{\text {presc }}$, i.e., large $D_{\mathrm{a}}$ ). The parameter $\kappa_{\mathrm{a}}$ characterizes the average hygroscopicity of $\mathrm{CCN}$-active particles in the size range around $D_{\mathrm{a}}$. Thus, for the calculations performed in this study we assumed $\kappa_{\mathrm{a}}=0.51$ for $D \sim 190 \mathrm{~nm}$ and $\kappa_{\mathrm{a}}=0.19$ for $D \leq 60 \mathrm{~nm}$ (Table 1).

Alternatively, the activation diameter and corresponding hygroscopicity parameter were derived from the integral $\mathrm{CCN}$ concentration and the $\mathrm{CN}$ size distribution out of cloud (cf. Sect. 2.6). The apparent cut-off diameter of CCN activation $\left(D_{\text {cut }}\right)$ is the diameter above which the integral $\mathrm{CN}$ number concentration equals the observed integral CCN concentration $\left(N_{\mathrm{CCN} \text {,int }}\right)$. This is equivalent to the activation diameter obtained typically from integral $\mathrm{CCN}$ measurements (without size resolution), which was also used, for example, by Hammer et al. (2014).

The hygroscopicity parameter $\kappa_{\text {cut }}$ was determined from Eq. (B1) by inserting the activation diameter $D_{\text {cut }}$ for $D$ and varying both $\kappa$ and the droplet diameter $D_{\text {wet }}$ until $S$ was at the same time equal to the prescribed supersaturation $S_{\text {presc }}$ and to the maximum of Eq. (B1). The temperature $T$ used in Eq. (B1) was set to $298 \mathrm{~K}$. For the measurement period of our study, a range of $\kappa_{\text {cut }}$ values between 0.19 and 0.54 were

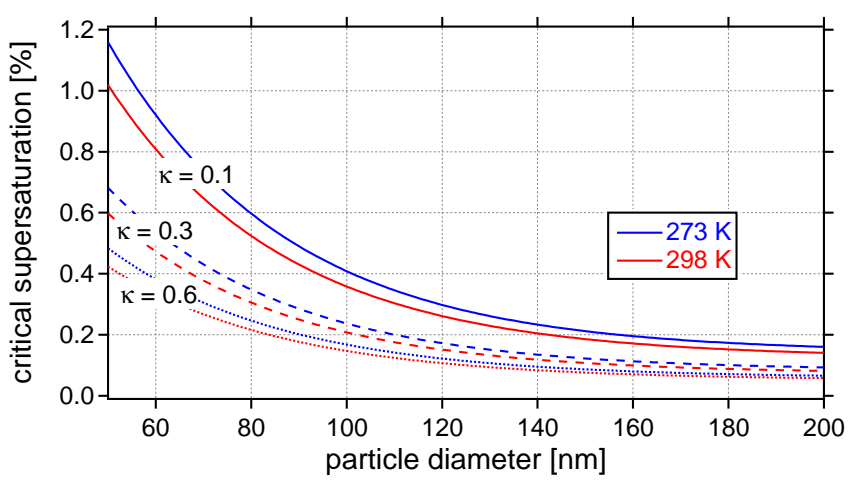

Figure C1. Critical supersaturation as a function of dry particle diameter calculated from Köhler theory (Appendix B) using different hygroscopicity parameters and temperatures as input parameters.

obtained for the different combinations of $S_{\text {presc }}$ and $D_{\text {cut }}$ (highest values for low $S_{\text {presc }}$, i.e., large $D_{\text {cut }}$ ). The parameter $\kappa_{\text {cut }}$ characterizes the average hygroscopicity of $\mathrm{CCN}$-active particles in the size range around $D_{\text {cut }}$. Differences between $\kappa_{\mathrm{a}}$ and $\kappa_{\text {cut }}$ mainly result from the shape of the particle number size distribution and from the heterogeneity of the particle composition, and have been discussed in detail by Rose et al. (2010). For the calculations performed in this study, we assumed $\kappa_{\text {cut }}=0.48$ for $D \sim 190 \mathrm{~nm}$ and $\kappa_{\text {cut }}=0.20$ for $D \leq 60 \mathrm{~nm}$ (Table 1).

In Sect. 3.2 of this paper, the critical supersaturation $\left(S_{\text {crit }}\right)$ as calculated from different pairs of observed dry activation diameters and prescribed $\kappa$ values was related to the cloud supersaturation. It was determined from Eq. (B1) by inserting the above-mentioned $\kappa$ values $\left(\kappa_{\mathrm{a}}, \kappa_{\text {cut }}, \kappa_{\mathrm{AMS}}\right.$, and $\left.\kappa_{\text {mean }}=0.3\right)$ and varying both $S$ and the droplet diameter $D_{\text {wet }}$ until $D$ was at the same time equal to the observed activation diameter and to the maximum of Eq. (B1). The temperature $T$ used in Eq. (B1) had to be set to the value at which the cloud was formed in the ambient air. It was assumed to be $\sim 273 \mathrm{~K}$, which was the average ambient air temperature during the cloud event.

\section{Appendix C: temperature scaling of supersaturation}

Due to the temperature dependence of the Kelvin effect, the critical supersaturation $\left(S_{\text {crit }}\right)$ for the CCN activation of an aerosol particle depends not only on its size and composition but also on the temperature at which the activation occurs. Thus, the supersaturation level at which a particle is activated at ambient temperature in a cloud is not necessarily the same as the supersaturation level at which the particle is activated at the instrument temperature in a CCNC.

To compensate for this effect, the supersaturation levels prescribed in the CCNC at a sample temperature of approximately $298 \mathrm{~K}\left(S_{\text {presc }}\right)$ were scaled to an equivalent 
supersaturation at an average ambient air temperature during the cloud event of $\sim 273 \mathrm{~K}\left(S_{\mathrm{CCNC}}\right)$.

For this purpose we performed Köhler theory calculations of $S_{\text {crit }}$ as a function of dry particle diameter for different hygroscopicity parameter values and temperatures (Fig. C1). For a given particle diameter, the relative difference of $S_{\text {crit }}$ at 273 vs. $298 \mathrm{~K}$ was $+14 \%$, independent of the other variables ( $S=0.06-0.7 \% ; D=50-200 \mathrm{~nm}, \kappa=0.1-0.6)$. Thus, we multiplied the supersaturation levels prescribed in the CCNC at $\sim 298 \mathrm{~K}\left(S_{\text {presc }}=0.06,0.11,0.22,0.45\right.$, and $\left.0.60 \%\right)$ by a factor of 1.14 to obtain the equivalent supersaturation levels for CCN activation in a cloud at $\sim 273 \mathrm{~K}\left(S_{\mathrm{CCNC}}=0.07\right.$, $0.13,0.25,0.51$, and $0.68 \%$ ), which were used for the derivation of the cloud peak supersaturation as specified in Sect. 3.1. 
Acknowledgements. This work has been supported by the Max Planck Society (MPG), the Max Planck Graduate Center with the Johannes Gutenberg University Mainz (MPGC), and the German Research Foundation (DFG-SPP 1294-HALO, grant PO 1013/2, grant SCHN 1138/1, grant ME 3534/1-2). We thank D. Rosenow, M. Wendisch, and the ACRIDICON-Zugspitze team for collaboration and support. The team of the Environmental Research Station Schneefernerhaus (UFS) is acknowledged for logistical support and access to the Schneefernerhaus field site. The authors wish to thank K. Selzle, C. Pöhlker, S. S. Gunthe, E. Mikhailov, L. M. Russell, M. Gysel, E. Hammer, F. Ditas, A. Wiedensohler, and M. Schäfer for support and stimulating discussions.

The service charges for this open access publication have been covered by the Max Planck Society.

Edited by: P. Herckes

\section{References}

Andreae, M. O. and Rosenfeld, D.: Aerosol-cloudprecipitation interactions. Part 1 . The nature and sources of cloud-active aerosols, Earth-Sci. Rev., 89, 13-41, doi:10.1016/j.earscirev.2008.03.001, 2008.

Anttila, T., Vaattovaara, P., Komppula, M., Hyvärinen, A.-P., Lihavainen, H., Kerminen, V.-M., and Laaksonen, A.: Sizedependent activation of aerosols into cloud droplets at a subarctic background site during the second Pallas Cloud Experiment (2nd PaCE): method development and data evaluation, Atmos. Chem. Phys., 9, 4841-4854, doi:10.5194/acp-9-4841-2009, 2009.

Anttila, T., Brus, D., Jaatinen, A., Hyvärinen, A.-P., Kivekäs, N., Romakkaniemi, S., Komppula, M., and Lihavainen, H.: Relationships between particles, cloud condensation nuclei and cloud droplet activation during the third Pallas Cloud Experiment, Atmos. Chem. Phys., 12, 11435-11450, doi:10.5194/acp12-11435-2012, 2012.

Asmi, E., Freney, E., Hervo, M., Picard, D., Rose, C., Colomb, A., and Sellegri, K.: Aerosol cloud activation in summer and winter at puy-de-Dôme high altitude site in France, Atmos. Chem. Phys., 12, 11589-11607, doi:10.5194/acp-12-11589-2012, 2012.

Canagaratna, M. R., Jayne, J. T., Jimenez, J. L., Allan, J. D., Alfarra, M. R., Zhang, Q., Onasch, T. B., Drewnick, F., Coe, H., Middlebrook, A., Delia, A., Williams, L. R., Trimborn, A. M., Northway, M. J., DeCarlo, P. F., Kolb, C. E., Davidovits, P., and Worsnop, D. R.: Chemical and microphysical characterization of ambient aerosols with the aerodyne aerosol mass spectrometer, Mass Spectr. Rev., 26, 185-222, 2007.

Christensen, S. I. and Petters, M. D.: The Role of Temperature in Cloud Droplet Activation, J. Phys. Chem. A, 116, 9706-9717, doi:10.1021/jp3064454, 2012.

Ditas, F., Shaw, R. A., Siebert, H., Simmel, M., Wehner, B., and Wiedensohler, A.: Aerosols-cloud microphysicsthermodynamics-turbulence: evaluating supersaturation in a marine stratocumulus cloud, Atmos. Chem. Phys., 12, 2459-2468, doi:10.5194/acp-12-2459-2012, 2012.

Drewnick, F., Hings, S. S., DeCarlo, P., Jayne, J. T., Gonin, M., Fuhrer, K., Weimer, S., Jimenez, J. L., Demerjian, K. L., Borrmann, S., and Worsnop, D. R.: A new time-of-flight aerosol mass spectrometer (TOF-AMS) - Instrument description and first field deployment, Aerosol Sci. Technol., 39, 637-658, doi:10.1080/02786820500182040, 2005.

Dusek, U., Frank, G. P., Hildebrandt, L., Curtius, J., Schneider, J., Walter, S., Chand, D., Drewnick, F., Hings, S., Jung, D., Borrmann, S., and Andreae, M. O.: Size matters more than chemistry for cloud-nucleating ability of aerosol particles, Science, 312, 1375-1378, doi:10.1126/science.1125261, 2006.

Dusek, U., Frank, G. P., Curtius, J., Drewnick, F., Schneider, J., Kurten, A., Rose, D., Andreae, M. O., Borrmann, S., and Poschl, U.: Enhanced organic mass fraction and decreased hygroscopicity of cloud condensation nuclei $(\mathrm{CCN})$ during new particle formation events, Geophys. Res. Lett., 37, L03804, doi:10.1029/2009g1040930, 2010.

Engelhart, G. J., Hennigan, C. J., Miracolo, M. A., Robinson, A. L., and Pandis, S. N.: Cloud condensation nuclei activity of fresh primary and aged biomass burning aerosol, Atmos. Chem. Phys., 12, 7285-7293, doi:10.5194/acp-12-7285-2012, 2012.

Frank, G. P., Dusek, U., and Andreae, M. O.: Technical note: A method for measuring size-resolved $\mathrm{CCN}$ in the atmosphere, Atmos. Chem. Phys. Discuss., 6, 4879-4895, doi:10.5194/acpd-64879-2006, 2006.

Gerber, H.: Direct measurement of suspended particulate volume concentration and far-infrared extinction coefficient with a laserdiffraction instrument, Appl. Opt., 30, 4824-4831, 1991.

Gunthe, S. S., King, S. M., Rose, D., Chen, Q., Roldin, P., Farmer, D. K., Jimenez, J. L., Artaxo, P., Andreae, M. O., Martin, S. T., and Pöschl, U.: Cloud condensation nuclei in pristine tropical rainforest air of Amazonia: size-resolved measurements and modeling of atmospheric aerosol composition and CCN activity, Atmos. Chem. Phys., 9, 7551-7575, doi:10.5194/acp-9-75512009, 2009.

Gunthe, S. S., Rose, D., Su, H., Garland, R. M., Achtert, P., Nowak, A., Wiedensohler, A., Kuwata, M., Takegawa, N., Kondo, Y., Hu, M., Shao, M., Zhu, T., Andreae, M. O., and Pöschl, U.: Cloud condensation nuclei $(\mathrm{CCN})$ from fresh and aged air pollution in the megacity region of Beijing, Atmos. Chem. Phys., 11, 1102311039, doi:10.5194/acp-11-11023-2011, 2011.

Hammer, E., Bukowiecki, N., Gysel, M., Jurányi, Z., Hoyle, C. R., Vogt, R., Baltensperger, U., and Weingartner, E.: Investigation of the effective peak supersaturation for liquid-phase clouds at the high-alpine site Jungfraujoch, Switzerland (3580 m a.s.1.), Atmos. Chem. Phys., 14, 1123-1139, doi:10.5194/acp-14-11232014, 2014.

Henning, S., Weingartner, E., Schmidt, S., Wendisch, M., Gaggeler, H. W. and Baltensperger, U.: Size-dependent aerosol activation at the high-alpine site Jungfraujoch $(3580 \mathrm{~m}$ asl), Tellus Ser. B-Chem. Phys. Meteorol., 54, 82-95, doi:10.1034/j.16000889.2002.00299.x, 2002.

Hoppel, W. A., Frick, G. M. and Fitzgerald, J. W.: Deducing droplet concentration and supersaturation in marine boundary layer clouds from surface aerosol measurements, J. Geophys. Res.-Atmos., 101, 26553-26565, doi:10.1029/96jd02243, 1996.

Jurányi, Z., Gysel, M., Weingartner, E., DeCarlo, P. F., Kammermann, L., and Baltensperger, U.: Measured and modelled cloud condensation nuclei number concentration at the high alpine site Jungfraujoch, Atmos. Chem. Phys., 10, 7891-7906, doi:10.5194/acp-10-7891-2010, 2010.

Jurányi, Z., Tritscher, T., Gysel, M., Laborde, M., Gomes, L., Roberts, G., Baltensperger, U., and Weingartner, E.: Hy- 
groscopic mixing state of urban aerosol derived from sizeresolved cloud condensation nuclei measurements during the MEGAPOLI campaign in Paris, Atmos. Chem. Phys., 13, 64316446, doi:10.5194/acp-13-6431-2013, 2013.

Kim, J. H., Yum, S. S., Shim, S., Yoon, S.-C., Hudson, J. G., Park, J., and Lee, S.-J.: On aerosol hygroscopicity, cloud condensation nuclei $(\mathrm{CCN})$ spectra and critical supersaturation measured at two remote islands of Korea between 2006 and 2009, Atmos. Chem. Phys., 11, 12627-12645, doi:10.5194/acp-1112627-2011, 2011.

Kinne, S.: Climatologies of Cloud-related Aerosol, Part 1: Particle Number and Size, in: Clouds in the Perturbed Climate System: Their Relationship to Energy Balance, Atmospheric Dynamics, and Precipitation, edited by: Heintzenberg, J. and Charlson, R. J., MIT Press, Cambridge, MA, USA, 37-57, 2009.

Köhler, H.: The nucleus in and the growth of hygroscopic droplets, Trans. Faraday Soc., 32, 1152-1161, doi:10.1039/tf9363201152, 1936.

Kulmala, M., Asmi, A., Lappalainen, H. K., Baltensperger, U., Brenguier, J.-L., Facchini, M. C., Hansson, H.-C., Hov, Ø., O'Dowd, C. D., Pöschl, U., Wiedensohler, A., Boers, R., Boucher, O., de Leeuw, G., Denier van der Gon, H. A. C., Feichter, J., Krejci, R., Laj, P., Lihavainen, H., Lohmann, U., McFiggans, G., Mentel, T., Pilinis, C., Riipinen, I., Schulz, M., Stohl, A., Swietlicki, E., Vignati, E., Alves, C., Amann, M., Ammann, M., Arabas, S., Artaxo, P., Baars, H., Beddows, D. C. S., Bergström, R., Beukes, J. P., Bilde, M., Burkhart, J. F., Canonaco, F., Clegg, S. L., Coe, H., Crumeyrolle, S., D’Anna, B., Decesari, S., Gilardoni, S., Fischer, M., Fjaeraa, A. M., Fountoukis, C., George, C., Gomes, L., Halloran, P., Hamburger, T., Harrison, R. M., Herrmann, H., Hoffmann, T., Hoose, C., Hu, M., Hyvärinen, A., Hõrrak, U., Iinuma, Y., Iversen, T., Josipovic, M., Kanakidou, M., Kiendler-Scharr, A., Kirkevåg, A., Kiss, G., Klimont, Z., Kolmonen, P., Komppula, M., Kristjánsson, J.-E., Laakso, L., Laaksonen, A., Labonnote, L., Lanz, V. A., Lehtinen, K. E. J., Rizzo, L. V., Makkonen, R., Manninen, H. E., McMeeking, G., Merikanto, J., Minikin, A., Mirme, S., Morgan, W. T., Nemitz, E., O’Donnell, D., Panwar, T. S., Pawlowska, H., Petzold, A., Pienaar, J. J., Pio, C., Plass-Duelmer, C., Prévôt, A. S. H., Pryor, S., Reddington, C. L., Roberts, G., Rosenfeld, D., Schwarz, J., Seland, Ø., Sellegri, K., Shen, X. J., Shiraiwa, M., Siebert, H., Sierau, B., Simpson, D., Sun, J. Y., Topping, D., Tunved, P., Vaattovaara, P., Vakkari, V., Veefkind, J. P., Visschedijk, A., Vuollekoski, H., Vuolo, R., Wehner, B., Wildt, J., Woodward, S., Worsnop, D. R., van Zadelhoff, G.-J., Zardini, A. A., Zhang, K., van Zyl, P. G., Kerminen, V.-M., S Carslaw, K., and Pandis, S. N.: General overview: European Integrated project on Aerosol Cloud Climate and Air Quality interactions (EUCAARI) - integrating aerosol research from nano to global scales, Atmos. Chem. Phys., 11, 13061-13143, doi:10.5194/acp11-13061-2011, 2011.

Lance, S., Raatikainen, T., Onasch, T. B., Worsnop, D. R., Yu, X.-Y., Alexander, M. L., Stolzenburg, M. R., McMurry, P. H., Smith, J. N., and Nenes, A.: Aerosol mixing state, hygroscopic growth and cloud activation efficiency during MIRAGE 2006, Atmos. Chem. Phys., 13, 5049-5062, doi:10.5194/acp-13-5049-2013, 2013.

Lohmann, U. and Feichter, J.: Global indirect aerosol effects: a review, Atmos. Chem. Phys., 5, 715-737, doi:10.5194/acp-5-7152005, 2005.
McFiggans, G., Artaxo, P., Baltensperger, U., Coe, H., Facchini, M. C., Feingold, G., Fuzzi, S., Gysel, M., Laaksonen, A., Lohmann, U., Mentel, T. F., Murphy, D. M., O’Dowd, C. D., Snider, J. R., and Weingartner, E.: The effect of physical and chemical aerosol properties on warm cloud droplet activation, Atmos. Chem. Phys., 6, 2593-2649, doi:10.5194/acp-6-2593-2006, 2006.

Mertes, S., Lehmann, K., Nowak, A., Massling, A., and Wiedensohler, A.: Link between aerosol hygroscopic growth and droplet activation observed for hill-capped clouds at connected flow conditions during FEBUKO, Atmos. Enviro., 39, 4247-4256, doi:10.1016/j.atmosenv.2005.02.010, 2005.

Mikhailov, E., Vlasenko, S., Rose, D., and Pöschl, U.: Mass-based hygroscopicity parameter interaction model and measurement of atmospheric aerosol water uptake, Atmos. Chem. Phys., 13, 717740, doi:10.5194/acp-13-717-2013, 2013.

Moore, R. H. and Nenes, A.: Scanning Flow CCN Analysis-A Method for Fast Measurements of CCN Spectra, Aerosol Sci. Technol., 43, 1192-1207, doi:10.1080/02786820903289780, 2009.

Padró, L. T., Moore, R. H., Zhang, X., Rastogi, N., Weber, R. J., and Nenes, A.: Mixing state and compositional effects on CCN activity and droplet growth kinetics of size-resolved $\mathrm{CCN}$ in an urban environment, Atmos. Chem. Phys., 12, 10239-10255, doi:10.5194/acp-12-10239-2012, 2012.

Petters, M. D. and Kreidenweis, S. M.: A single parameter representation of hygroscopic growth and cloud condensation nucleus activity, Atmos. Chem. Phys., 7, 1961-1971, 2007, http://www.atmos-chem-phys.net/7/1961/2007/.

Petters, M. D. and Kreidenweis, S. M.: A single parameter representation of hygroscopic growth and cloud condensation nucleus activity - Part 2: Including solubility, Atmos. Chem. Phys., 8, 6273-6279, doi:10.5194/acp-8-6273-2008, 2008.

Petters, M. D. and Kreidenweis, S. M.: A single parameter representation of hygroscopic growth and cloud condensation nucleus activity - Part 3: Including surfactant partitioning, Atmos. Chem. Phys., 13, 1081-1091, doi:10.5194/acp-13-1081-2013, 2013.

Pöschl, U.: Atmospheric aerosols: Composition, transformation, climate and health effects, Angewandte Chemie-International Edition, 44, 7520-7540, doi:10.1002/anie.200501122, 2005.

Pöschl, U., Rose, D., and Andreae, M. O.: Climatologies of cloudrelated aerosols, Part 2: Particle hygroscopicity and cloud condensation nucleus activity, in: Clouds in the Perturbed Climate System: Their Relationship to Energy Balance, Atmospheric Dynamics, and Precipitation, edited by: Heintzenberg, J. and Charlson, R. J., MIT Press, Cambridge, MA, USA, 57-72, 2009.

Pringle, K. J., Tost, H., Pozzer, A., Pöschl, U., and Lelieveld, J.: Global distribution of the effective aerosol hygroscopicity parameter for $\mathrm{CCN}$ activation, Atmos. Chem. Phys., 10, 52415255, doi:10.5194/acp-10-5241-2010, 2010.

Pruppacher, H. R. and Klett, J. D.: Microphysics of Clouds and Precipitation, Atmospheric and Oceanographic Sciences Library, 18, Springer Netherlands, 954 pp., 2010.

Renn, N. O., Williams, E., Rosenfeld, D., Fischer, D. G., Fischer, J., Kremic, T., Agrawal, A., Andreae, M. O., Bierbaum, R., Blakeslee, R., Boerner, A., Bowles, N., Christian, H., Cox, A., Dunion, J., Horvath, A., Huang, X., Khain, A., Kinne, S., Lemos, M. C., Penner, J. E., Pöschl, U., and Quaas, J.: CHASER An Innovative Satellite Mission Concept to Measure the Effects of 
Aerosols on Clouds and Climate, Bull. Am. Meteorol. Soc., 5 , 685-694, doi:10.1175/bams-d-11-00239.1, 2013.

Reutter, P., Su, H., Trentmann, J., Simmel, M., Rose, D., Gunthe, S. S., Wernli, H., Andreae, M. O., and Pöschl, U.: Aerosol- and updraft-limited regimes of cloud droplet formation: influence of particle number, size and hygroscopicity on the activation of cloud condensation nuclei (CCN), Atmos. Chem. Phys., 9, 70677080, doi:10.5194/acp-9-7067-2009, 2009.

Roberts, G. C. and Nenes, A.: A continuous-flow streamwise thermal-gradient $\mathrm{CCN}$ chamber for atmospheric measurements, Aerosol Sci. Technol., 39, 206-221, doi:10.1080/027868290913988, 2005.

Rose, D., Gunthe, S. S., Mikhailov, E., Frank, G. P., Dusek, U., Andreae, M. O., and Pöschl, U.: Calibration and measurement uncertainties of a continuous-flow cloud condensation nuclei counter (DMT-CCNC): CCN activation of ammonium sulfate and sodium chloride aerosol particles in theory and experiment, Atmos. Chem. Phys., 8, 1153-1179, doi:10.5194/acp-8-11532008, 2008.

Rose, D., Nowak, A., Achtert, P., Wiedensohler, A., Hu, M., Shao, M., Zhang, Y., Andreae, M. O., and Pöschl, U.: Cloud condensation nuclei in polluted air and biomass burning smoke near the mega-city Guangzhou, China - Part 1: Size-resolved measurements and implications for the modeling of aerosol particle hygroscopicity and CCN activity, Atmos. Chem. Phys., 10, 33653383, doi:10.5194/acp-10-3365-2010, 2010.

Rose, D., Gunthe, S. S., Su, H., Garland, R. M., Yang, H., Berghof, M., Cheng, Y. F., Wehner, B., Achtert, P., Nowak, A., Wiedensohler, A., Takegawa, N., Kondo, Y., Hu, M., Zhang, Y., Andreae, M. O., and Pöschl, U.: Cloud condensation nuclei in polluted air and biomass burning smoke near the mega-city Guangzhou, China - Part 2: Size-resolved aerosol chemical composition, diurnal cycles, and externally mixed weakly $\mathrm{CCN}$-active soot particles, Atmos. Chem. Phys., 11, 2817-2836, doi:10.5194/acp-112817-2011, 2011.
Rosenfeld, D., Lohmann, U., Raga, G. B., O’Dowd, C. D., Kulmala, M., Fuzzi, S., Reissell, A., and Andreae, M. O.: Flood or drought: How do aerosols affect precipitation?, Science, 321, 1309-1313, doi:10.1126/science.1160606, 2008.

Rosenfeld, D., Williams, E., Andreae, M. O., Freud, E., Pöschl, U., and Rennó, N. O.: The scientific basis for a satellite mission to retrieve $\mathrm{CCN}$ concentrations and their impacts on convective clouds, Atmos. Meas. Tech., 5, 2039-2055, doi:10.5194/amt-52039-2012, 2012.

Russell, L. M., Sorooshian, A., Seinfeld, J. H., Albrecht, B. A., Nenes, A., Ahlm, L., Chen, Y. C., Coggon, M., Craven, J. S., Flagan, R. C., Frossard, A. A., Jonsson, H., Jung, E., Lin, J. J., Metcalf, A. R., Modini, R., Mulmenstadt, J., Roberts, G. C., Shingler, T., Song, S., Wang, Z., and Wonaschutz, A.: Eastern Pacific Emitted Aerosol Cloud Experiment, Bull. Am. Meteorol. Soc., 94, 709-729, doi:10.1175/BAMS-D-12-00015.1, 2013.

Solomon, S., Qin, D., Manning, Z., Chen, Z., Marquis, M., Avery, K. B., Tignor, M., and Miller, H. L. E.: IPCC 4th Assessment Report, Cambridge Univ. Press, Cambridge, 2007.

Spracklen, D. V., Carslaw, K. S., Pöschl, U., Rap, A., and Forster, P. M.: Global cloud condensation nuclei influenced by carbonaceous combustion aerosol, Atmos. Chem. Phys., 11, 9067-9087, doi:10.5194/acp-11-9067-2011, 2011.

Su, H., Rose, D., Cheng, Y. F., Gunthe, S. S., Massling, A., Stock, M., Wiedensohler, A., Andreae, M. O., and Pöschl, U.: Hygroscopicity distribution concept for measurement data analysis and modeling of aerosol particle mixing state with regard to hygroscopic growth and CCN activation, Atmos. Chem. Phys., 10, 7489-7503, doi:10.5194/acp-10-7489-2010, 2010.

Wex, H., McFiggans, G., Henning, S., and Stratmann, F.: Influence of the external mixing state of atmospheric aerosol on derived CCN number concentrations, Geophys. Res. Lett., 37, L10805, doi:10.1029/2010g1043337, 2010. 